\title{
PENGARUH PENAMBAHAN SARI JAMUR TIRAM PUTIH (Pleurotus ostreatus) PADA PEMBUATAN YOGURT DRINK DITINJAU DARI SIFAT MUTU FISIK
}

\author{
Effect of The Addition of White Oyster Mushroom (Pleurotus ostreatus) Extract \\ on The Manufacture of Yogurt Drink in Terms of Physical Quality \\ Digna Anissa Prabowo' ${ }^{1)}$, Lilik Eka Radiati ${ }^{2)}$ \\ 1) Fakultas Peternakan, Universitas Brawijaya. Jl. Veteran, Malang, Jawa Timur, Indonesia, 65145 \\ ${ }^{2)}$ Fakultas Peternakan, Universitas Brawijaya. Jl. Veteran, Malang, Jawa Timur, Indonesia, 65145 \\ Emai: dignanissa@gmail.com
}

Diterima 28 Agustus 2018; diterima pasca revisi 23 Oktober 2018

Layak diterbitkan 30 Oktober 2018

\begin{abstract}
The white oyster mushroom extract containing proteins, carbohydrate and some glucose, in white oyster mushrooms containing $\beta$-glucan. The aim of this research was to determine the effect of the addition white oyster mushroom extract on viscosity, water holding capacity and moisture content on the yogurt drink. The result of the research provides information on the usage of white oyster mushroom extract onto yogurt drink. The research method was experimental design using Completely Randomized Design (CRD) with 4 treatment, consist of $P 0, P 1, P 2$ and $P 3$, and 4 replications and continued by Duncan's Multiple Range Test (DMRT). The result showed that addition of 3\% white oyster mushroom extract gave highly significantly different $(P<0.01)$ on viscosity and moisture content and the addition of white oyster mushroom extract in yogurt drink gave significant different $(P<0.05)$ on water holding capacity. Based on the analysis of the research, it can be concluded that use of white oyster mushroom extract with the concentration until 3\% can increase in viscosity and in water holding capacity and decrease moisture content.
\end{abstract}

Keyword : Yogurt; oyster mushroom extract; viscosity; water holding capacity; moisture content

\section{ASBTRAK}

Sari jamur tiram putih mengandung protein, karbohidrat dan beberapa glukosa, dalam jamur tiram putih juga mengandung $\beta$-glukan. Tujuan dari penelitian ini adalah untuk mengetahui pengaruh penambahan sari jamur tiram putih ditinjau dari viskositas, daya ikat air dan kadar air pada yogurt drink. Hasil penelitian memberikan informasi tentang penambahan sari jamur tiram putih dalam yogurt drink. Metode penelitian yang digunakan adalah Rancangan Acak Lengkap (RAL) dengan 4 perlakuan, terdiri dari P0, P1, P2 dan P3, dan 4 ulangan dan dilanjutkan dengan Uji Jarak Berganda Duncan (UJBD). Hasil penelitian menunjukkan bahwa penambahan $3 \%$ sari jamur tiram putih memberikan perbedaan sangat nyata $(P<0,01)$ pada viskositas dan kadar air dan memberikan perbedaan yang signifikan $(P<0,05)$ pada daya ikat air. Berdasarkan analisis penelitian, dapat disimpulkan bahwa penggunaan sari jamur tiram putih dengan konsentrasi hingga 3\% dapat meningatkan viskositas dan daya ikat air serta menurunkan kadar air.

Kata kunci : Yogurt; sari jamur tiram putih; viskositas; daya ikat air; kadar air. 


\section{PENDAHULUAN}

Yogurt adalah produk yang dibuat dari susu melalui proses fermentasi bakteri asam laktat Lactobacillus bulgaricus dan Streptococcus thermophilus. Pada dasarnya kerja bakteri yogurt adalah mengasilkan asam laktat yang penting perannya untuk menciptakan keseimbangan mikroflora usus, keasaman yang dihasilkan mampu menghambat bakteri penyebab penyakit yang umumnya tidak tahan terhadap asam. Yogurt sangat baik untuk kesehatan, terutama untuk menjaga keasaman lambung dan dapat menekan pertumbuhan bakteri patogen di usus. Selain itu, yogurt juga mengandung kadar protein yang tinggi. Hal ini disebabkan penambahan protein dari sintesa mikroba dan kandungan protein dari mikroba tersebut (Winarno, 2007).

Kelemahan produk yogurt yaitu pada proses pembuatannya terjadi penurunan daya ikat air (whey off), hal ini disebabkan $\mathrm{pH}$ yogurt berada di kisaran titik isoelektrik kasein. Gel kasein yang berada pada lingkungan $\mathrm{pH}$ isoelektrik mempunyai daya pengikatan molekul air yang relatif lemah, mendorong pelepasan molekul air pada permukaan gel atau sineresis dan penurunan viskositas atau kekentalan (Alakali, Okonkwo and Iordye, 2008). Penurunan daya ikat air ini dapat mempengaruhi kualitas akhir produk yogurt. Alternatif untuk mengantisipasi masalah ini dengan cara menambahkan stabilizer (Agarwal dan Prasad, 2008). Selain mampu untuk mengikat air yang merupakan media pertumbuhan bakteri, fungsi stabilizer yang lain yaitu dapat meningkatkan masa simpan yogurt dengan menekan pertumbuhan bakteri pembusuk (Utomo, Purwadi dan Thohari, 2013). Penstabil ini akan menurunkan terjadinya sineresis, meningkatkan viskositas hasil

*Corresponding author :

Digna Anissa Prabowo

Email : dignanissa@gmail.com

Fakultas Peternakan, Universitas Brawijaya. Jl.

Veteran, Malang, Jawa Timur, Indonesia, 65145 olahan sehingga memperbaiki stabilitas emulsi serta meningkatkan prebiotik pada produk. Fakultas Peternakan Universitas Brawijaya telah mengawali melakukan penelitian yogurt dengan menambahkan gelatin sebagai stabilizer. Berdasarkan hasil penelitian Sawitri dkk, (2008) penggunaan gelatin sebagai stabilizer mampu memberikan pengaruh yang nyata terhadap tekstur yogurt $(\mathrm{P}<0,05)$. Namun kenyataannya kebutuhan stabilizer di Indonesia selama ini masih bergantung pada impor dari negara-negara Eropa, Amerika, Australia dan Cina dengan harga yang mahal.

Jamur tiram putih secara luas dihargai di seluruh dunia karena nilai gizi dan sifat pengobatan. Jamur tiram putih mengandung protein tinggi, beberapa mineral dan elemen, serta sejumlah serat makanan. Jamur Basidiomycetes (filum Basidiomycota) juga merupakan produsen molekul bioaktif dan enzim yang berharga dengan lebih dari 126 efek terapi yang berbeda (Wasser, 2002; Wasser, 2010; Badalyan, 2012). Kelompok utama molekul bioaktif yang dihasilkan oleh jamur tiram, diantaranya polisakarida, terpenoid, fenolat, lektin, statin dan lain-lain. Jamur tiram memiliki kekebalan modulasi, antioksidan, antitumor, antidiabetes dan efek pengobatan lainnya (Wasser, 2010; Lindequist, 2005; Badalyan, 2012). Bglukan adalah salah satu zat dalam jamur tiram putih yang berperan sebagai obat. $\beta$ glukan adalah suatu jenis polisakarida dengan monomer berupa D-glukosa yang diikat melalui ikatan $\beta-(1,3)$ glukosida dan B-(1,6) glukosida. B-glukan terdapat pada jamur tiram putih dan dinyatakan tidak mengakibatkan efek samping serta tidak beracun. Adanya ß-glukan pada jamur timur dapat digunakan sebgai stabilizer dalam produk yogurt.
How to cite :

Prabowo, D.A., Radiati, L.E. (2018). Pengaruh Penambahan Sari Jamur Tiram Putih (Pleurotus ostreatus) pada Pembuatan Yogurt Drink Ditinjau dari Sifat Mutu Fisik. Jurnal Ilmu dan Teknologi Hasil Ternak, 13 (2), 118-125 
Polisakarida fungi merupakan subtansi antitumor dan immune-modulating yang paling potensial dari jamur, yang terdapat pada dinding sel. Polisakarida adalah karbohidrat dengan molekul yang terbuat dari berbagai unit gula yang terikat bersama. Polisakarida dapat didefinisikan sebagai rantai panjang monosakarida (bentuk sederhana dari gula, misalnya fruktosa, glukosa, ribosa dan lain lain). Polisakarida dapat dimanfaatkan sebagai stabilitas dalam pembuatan produk pangan.

Selama ini belum ada kajian terkait pemanfaatan potensi sari jamur tiram putih untuk meningkatkan kualitas yogurt didasarkan pada sifat fisiko-kimia. Perlu dilakukan penelitian tentang pengujian penambahan sari jamur tiram putih untuk memperbaiki permasalahan pada proses pembuatan produk yogurt, sehingga dapat menghasilkan produk akhir yogurt yang terbaik, serta dapat menunjang pemenuhan kebutuhan konsumsi masyarakat terhadap bahan pangan fungsional dan menurunkan ketergantungan pada produk impor.

\section{MATERI DAN METODE}

Bahan utama yang digunakan dalam pembuatan sari jamur tiram putih adalah jamur tiram putih yang bersih yang didapatkan di pasar Merjosari dan aquabides yang didapatkan di toko kesehatan. Sari jamur tiram putih yaitu, timbangan analitik, beaker glass, pisau, blender, panci, kompor, pengaduk, kain saring. Bahan utama dalam pembuatan yogurt adalah susu murni yang dilakukan uji alkohol, starter sebanyak $3 \%$.

Tahap pertama penelitian ini adalah pembuatan sari jamur tiram putih. Tahap selanjutnya pembuatan yogurt drink yang diberi penambahan sari jamur tiram putih. Metode yang digunakan dalam penelitian ini adalah percobaan. Rancangan yang digunakan adalah Rancangan Acak Lengkap (RAL) yang terdiri dari 4 perlakuan dan 4 ulangan. Perlakuan dalam penelitian ini adalah P0 tanpa penambahan sari jamur tiram putih;

P1 : Penambahan sari jamur tiram putih $1 \%$;

P2 : Penambahan sari jamur tiram putih $2 \%$;

P3 : Penambahan sari jamur tiram putih $3 \%$.

Parameter uji pada penelitian ini adalah nilai viskositas (AOAC, 2005); daya ikat air (Isanga dan Zhang, 209) dan kadar air (AOAC, 2005). Data yang diperoleh dari pengujian viskositas, daya ikat air dan kadar air diolah dengan bantuan Microsoft Excel, setelah data rata-rata diperoleh, kemudian dianalisis menggunakan analisis ragam dan dilanjutkan dengan Uji Jarak Berganda Duncan (UJBD).

\section{HASIL DAN PEMBAHASAN}

\section{Hasil Yogurt Drink dengan Penambahan Sari Jamur Tiram Putih}

Viskositas, daya ikat air dan kadar air yogurt dengan penambahan sari jamur tiram putih sebanyak $0 \%, 1 \%, 2 \%$ dan $3 \%$, disajikan pada Tabel 1.

\section{Viskositas Yogurt Drink}

Hasil analisis ragam menunjukkan perbedaan yang sangat nyata $(\mathrm{P}<0,01)$ diantara penambahan sari jamur tiram putih terhadap viskositas. Hasil Uji Jarak Berganda Duncan (UJBD) antar perlakuan menunjukkan perbedaan yang sangat nyata $(\mathrm{P}<0,01)$. Nilai viskositas berturut-turut $\mathrm{P} 0$, $\mathrm{P} 1, \mathrm{P} 2$, dan $\mathrm{P} 3$ sebagai berikut :

$\mathrm{P} 0$ sebesar 280,25 cP,

$\mathrm{P} 1$ sebesar $390 \mathrm{cP}$,

$\mathrm{P} 2$ sebesar $460 \mathrm{cP}$

P3 sebesar $870 \mathrm{cP}$.

Penambahan sari jamur tiram putih yang paling tinggi (3\%) menghasilkan viskositas yang paling tinggi. 
Tabel 1. Nilai Viskositas (cP), Daya Ikat Air (\%) dan Kadar Air (\%)

\begin{tabular}{cccc}
\hline Perlakuan & Viskositas** $(\mathrm{cP})$ & Daya Ikat Air* $(\%)$ & Kadar Air** $\left.(\%)^{\mathrm{a}}{ }^{\mathrm{a}}\right)$ \\
\hline P0 $(0 \%)$ & $280,25 \pm 4,99^{\mathrm{a}}$ & $56,225 \pm 1,77^{\mathrm{a}}$ & $87,80 \pm 0,10^{\mathrm{d}}$ \\
P1 $(1 \%)$ & $390 \pm 4,76^{\mathrm{b}}$ & $57,775 \pm 0,65^{\mathrm{b}}$ & $87,45 \pm 0,58^{\mathrm{c}}$ \\
P2 $(2 \%)$ & $460 \pm 4,76^{\mathrm{c}}$ & $58,225 \pm 0,32^{\mathrm{c}}$ & $86,32 \pm 0,54^{\mathrm{b}}$ \\
P3 (3\%) & $870 \pm 3,16^{\mathrm{d}}$ & $58,975 \pm 0,54^{\mathrm{d}}$ & $85,95 \pm 0,36^{\mathrm{a}}$ \\
\hline Keterangan : * & notasi yang berbeda pada kolom yang sama menunjukkan perbedaan yang nyata $(\mathrm{P}<0,05)$. \\
& ** notasi yang berbeda pada kolom yang sama menunjukkan perbedaan yang sangat nyata \\
&
\end{tabular}

Hal ini disebabkan oleh sari jamur tiram putih terdapat B-glukan sebagai penghasil polisakarida. Jamur tiram putih terdapat molekul bioaktif yaitu: polisakarida, terpenoid, fenolat, lektin, statin dan lain-lain. Adanya polisakarida dalam jamur tiram putih dapat dimanfaatkan sebagai penstabil yang mampu mengikat air yang merupakan media pertumbuhan bakteri.

Standar viskositas yogurt drink belum ada, akan tetapi rata-rata nilai viskositas ini secara umum tidak jauh berbeda untuk yogurt tanpa pernambahan sari jamur tiram putih, diperoleh nilai sebesar 280,25 cP, sesuai dengan pendapat Fauzi (2015) yang menyatakan bahwa nilai rata-rata viskositas berkisar antara 183-241 cP. Namun, pada yogurt drink dengan penambahan sari jamur tiram putih menunjukkan nilai viskositas yang semakin meningkat dan nilainya lebih tinggi, kurang sesuai dengan pendapat dari Setianto, Pramono dan Ulyani (2014) yang menyatakan bahwa yogurt drink, dengan penambahan penstabil memiliki nilai rata-rata viskositas sebesar 56,36-73,48 cP.

Hasil viskositas yang signifikan diduga karena protein susu yang terkoagulasi berbeda sehingga menghasilkan viskositas yang berbeda. Hal ini sesuai dengan pendapat Manab, (2008) yang menyatakan bahwa pada $\mathrm{pH}$ mendekati 4,6 kelarutan kasein sudah hilang sehingga terjadi interaksi hidrofobik antara misel kasein membentuk struktur dan konsistensi utama yogurt. Proses tersebut dapat mempengaruhi sifat fisik dari yogurt, diantaranya adalah tekstur, viskositas, daya ikat air dan sineresis. Viskositas yang tinggi juga disebabkan karena jamur tiram putih mengandung $\beta$ glukan yang dapat membentuk gel sehingga yogurt drink dengan penambahan sari jamur tiram putih menjadi lebih kental.

Hal ini sesuai dengan pendapat Budiyanto dan Yulianingsih, (2008) bahwa pektin berguna dalam pembentukan gel dan bahan penstabil, begitupula dengan $\beta$ glukan yang berguna sebagai bahan penstabil. Menurut pendapat Sirotek, et al., (2004) bahwa pektin adalah suatu komponen serat yang terdapat pada lapisan lamella tengah dan dinding sel primer pada tanaman, sama halnya dengan ß-glukan yang merupakan serat pangan yang terdapat dalam dinding sel jamur tiram putih. Hal ini sesuai dengan pendapat Goncalves et al. (2005) yang menyatakan bahwa semakin banyaknya konsentrasi pengental, kapasitas pengikatan air juga akan semakin meningkat.

Madora et al, (2016) menyatakan bahwa konsistensi yogurt menurun ketika kadar total padatan lebih rendah dari 16$20 \%$ yang menunjukkan bahwa viskositas yogurt menurun. Peningkatan nilai viskositas terjadi karena semakin banyak penambahan sari jamur tiram putih yang memiliki kandungan air yang rendah, sehingga menyebabkan penurunan kandungan air pada yogurt drink. Shaker, Jumah dan Abu-Jdayl (2000) menyatakan bahwa, penurunan jumlah total solid susu akan berpengaruh terhadap pembentukan gel pada proses fermentasi, sehingga mengakibatkan penurunan nilai viskositas pada yogurt. 


\section{Daya Ikat Air Yogurt Drink}

Hasil analisis ragam menunjukkan perbedaan yang nyata $(\mathrm{P}<0,05)$ diantara penambahan sari jamur tiram putih terhadap daya ikat air. Hasil Uji Jarak Berganda Duncan (UJBD) antar perlakuan menunjukkan perbedaan yang nyata $(\mathrm{P}<0,05)$. Nilai daya ikat air berturut-turut P0, P1, P2, dan P3 sebagai berikut, P0 sebesar 56,22\%, P1 sebesar 57,77\%, P2 sebesar 58,22\%, dan P3 sebesar 58,97\%. Penambahan sari jamur tiram putih yang paling tinggi $(3 \%)$ menghasilkan daya ikat air yang paling tinggi.

Nilai daya ikat air tertinggi adalah pada penambahan sari jamur tiram putih sebanyak 3\% dengan nilai rata-rata sebesar $58,975 \%$, hal ini sesuai dengan pendapat Febrisiantoso dan Purwanto (2012) yang menyatakan bahwa rata-rata nilai daya ikat air pada yogurt dengan penambahan bahan whey berkisar antara 59-62\%, hal ini disebabkan penambahan whey dapat menghambat ikatan hidrogen. Menurut Amal et al., (2016) nilai rata-rata daya ikat air pada yogurt drink adalah $58,28 \%$, nilai tersebut sesuai dengan hasil penelitian pembuatan yogurt drink dengan penambahan sari jamur tiram putih.

Hal ini disebabkan karena sari jamur tiram putih dapat meningkatkan daya ikat air yogurt dengan cara mencegah terjadinya ikatan hidrogen antara molekul kasein dan asam laktat dan meningkatkan sifat hidrofilik protein. penambahan bahan penstabil; misalnya gelatin, dapat menghambat ikatan hidrogen antara molekul kasein dan molekul asam laktat dan mempertahankan pengikatan molekul air oleh molekul protein.

Daya ikat air yogurt memiliki kemiringan (slope) yang positif, dimana semakin tinggi konsentrasi sari jamur tiram putih yang ditambahkan maka daya ikat air juga mengalami peningkatan.

Molekul air tertahan di dalam fase semi padatan karena adanya ikatan hidrogen $(\mathrm{C}==\mathrm{H})$ antara molekul air dengan grup amida protein $(\mathrm{N}--\mathrm{H})$, dan interaksi antara molekul air dengan grup ionik untuk membentuk struktur hidrasi yang terdiri dari ikatan hidrogen antar molekul air.

Menurut Decker (2001), molekul kasein mengalami perubahan muatan ion dari negatif ke positif karena berinteraksi dengan sari jamur tiram putih pada saat $\mathrm{pH}$ yogurt mencapai titik isoelektrik kasein sehingga kasein dan asam laktat tidak dapat saling berikatan karena memiliki muatan ion yang sama.

Gelatin sebagai bahan penstabil juga dapat meningkatkan daya ikat air yogurt dengan cara mencegah terjadinya ikatan hidrogen antara molekul kasein antara molekul kasein dan asam laktat, serta memicu terjadinya perubahan muatan ion kasein dan mempertahankan ikatan antar molekul protein sehingga kecenderungan molekul kasein yang bermuatan negatif untuk berikatan dengan molekul asam laktat yang bermuatan positif melalui ikatan hidrogen dapat dicegah. Penambahan bahan penstabil menyebabkan peningkatan sifat hidrofilik protein sehingga kemampuannya untuk mengikat air meningkat.

\section{Kadar Air Yogurt Drink}

Hasil analisis ragam menunjukkan perbedaan yang sangat nyata $(\mathrm{P}<0,01)$ diantara penambahan sari jamur tiram putih terhadap kadar air. Hasil Uji Jarak Berganda Duncan (UJBD) antar perlakuan menunjukkan perbedaan yang sangat nyata $(\mathrm{P}<0,01)$. Nilai kadar air berturut-turut $\mathrm{P} 0$, P1, P2, dan P3 sebagai berikut, P0 sebesar $87,80 \%$, P1 sebesar $87,45 \%$, P2 sebesar $86,32 \%$, dan $\mathrm{P} 3$ sebesar $85,95 \%$.

Penambahan sari jamur tiram putih yang paling tinggi (3\%) menghasilkan kadar air yang paling rendah. Hal ini disebabkan karena semakin banyak air yang terikat, maka nilai kadar air yang akan rendah. Kadar air pada yogurt drink tanpa penambahan sari jamur tiram putih menunjukkan hasil yang cukup sesuai dengan kadar air yogurt pada umumnya yaitu $85,95 \%$ pada P3, sesuai dengan pendapat Fauzi (2015) yang menyatakan 
bahwa, kadar air pada yogurt drink yaitu 86-89\%. Yogurt dengan kisaran nilai kadar air tersebut memiliki konsistensi yang kental hingga semi padat (Anonimous, 2009).

Kadar air yang lebih sedikit, menjadikan yogurt sebagai produk yang memiliki masa simpan yang cukup panjang. Kadar air dalam suatu bahan pangan dapat mempengaruhi aktivitas metabolisme dalam bahan pangan. Penambahan enzim dan BAL mampu menurunkan nilai kadar air produk (Miskiyah et al., 2011). Proses pemutusan ikatan peptida yang terdapat pada protein dalam proses hidrolisis protein oleh enzim protease juga membutuhkan air. Semakin aktif daya proteolitiknya semakin banyak kebutuhan akan air, sehingga akan menurunkan nilai aktivitas air dari bahan (Winarno dan Fernandez, 2007).

Tabel 1. menunjukkan bahwa kadar air terendah terdapat pada perlakuan P3 dengan penambahan konsentrasi sari jamur tiram putih sebanyak 3\%. Hal ini membuktikan bahwa dengan semakin banyaknya konsentrasi sari jamur tiram putih yang ditambahkan maka kadar air dair yogurt drink akan semakin rendah.

Semakin tingginya kekentalan suatu produk akan menyebabkan kadar air dari suatu produk menjadi lebih rendah. Jika dalam air (gugus hidroksil) sari jamur tiram akan membentuk ikatan hidrogen dengan molekul-molekul air sekitarnya, jika air dihilangkan akan terjadi pengkristalan, karena gugus hidroksil akan membentuk ikatan hidrogen dengan ikatan gugus hidroksil yang lain sesama monomer, oleh karena itu semakin banyak sari jamur tiram yang ditambahkan penguapan air dari kadar air bahan akan semakin rendah.

Nilai kadar air pada yogurt sangat bervariasi, karena adanya perbedaan kualitas susu yang digunakan dalam pembuatan yogurt drink. Askar dan Sugiarto (2005), menyatakan bahwa kadar air sampel yogurt bervariasi antara 71-90\%, nilai kadar air tersebut sesuai dengan nilai kadar air pada yogurt dengan penambahan sari jamur tiram putih, dimana sebesar
$87,80 \%-85,95 \%$ dari $\mathrm{P} 0$ hingga $\mathrm{P} 3$, variasi nilai kadar air ini disebabkan karena susu yang digunakan sebagai bahan dasar pembuatan yogurt kualitasnya berbedabeda, ada yang encer dan ada pula yang kental.

Proses pengolahan juga berpengaruh terhadap produk akhir dari yogurt drink yang dihasilkan. Celik et al, (2006) menyatakan bahwa, semakin tingginya kadar air maka nilai kekentalan akan rendah, begitu pula sebaliknya, apabila kada air semakin rendah, maka nilai kekentalan akan tinggi. Semakin tinggi pula nilai kadar air akan menyebabkan kerusakan pada yogurt.

\section{KESIMPULAN}

Penambahan sari jamur tiram putih pada pembuatan yogurt drink meningkatkan nilai viskositas, meningkatkan daya ikat dan menurunkan kadar air. Rataan nilai viskositas yogurt yang dihasilkan dalam penelitian adalah $280,25 \mathrm{cP} \pm 4,99$ pada $\mathrm{P} 0$ dan meningkat pada $\mathrm{P} 3$ yaitu $870 \mathrm{cP} \pm 3,16$. Rataan nilai daya ikat air yogurt yang dihasilkan dalam penelitian adalah $56,22 \% \pm 1,77$ pada $\mathrm{P} 0$ dan meningkat pada P3 yaitu 58,97\% \pm 0,54 . Rataan nilai kadar air yogurt yang dihasilkan dalam penelitian adalah $87,80 \%$ $\pm 0,10$ pada $\mathrm{P} 0$ dan menurun pada $\mathrm{P} 3$ yaitu $85,95 \% \pm 0,36$.

\section{DAFTAR PUSTAKA}

(AOAC). (2005). Official Methods of Analisys Chemis (Vol 1A). Washington, DC: AOAC,Inc.

Abdul, M. (2008). Physical Properties of yogurt during storage at $4^{\circ} \mathrm{C}$. Jurnal Ilmu Dan Teknologi Hasil Ternak, 3(1), 52-58.

Agarwal, R., \& Prasad, J. (2008). A conceptual and operational definition of personal innovativeness in the domain of information technology. 
Information Systems Research, 9(2), 204-215. https://doi.org/10.1287/isre.9.2.204

Amal, A. M., Eman, A. M. M., \& Zidan, N. (2016). Fruit flavored yogurt: chemical, functional and rheological properties. Journal International of Environmental and Agriculture Research, 2(5), 57-66.

Budiyanto, A., \& Yulianingsih. (2008). Pengaruh suhu dan waktu ekstraksi terhadap karakter pektin dari ampas jeruk siam (Citrus nobilis L.). Jurnal Penelitian Pascapanen Pertanian, 5(2), 37-44.

Celik, S., Bakırc1, I., \& Şat, I. (2006). Physicochemical and organoleptic properties of yogurt with cornelian cherry paste. International Journal of Food Properties, 9(3), 401-408. https://doi.org/10.1080/10942910600596258

Decker, K. J. (2001). The Dominant Culture: Yogurt for The Masses. New York: Tata MC Graw Hill Publisher Company.

Fauzi, I. (2015). Pengaruh Penambahan Sari Wortel pada Proses Pembuatan Yogurt Ditinjau Dari Organoleptik, Kadar Air dan Viskositas. Universitas Brawijaya Malang.

Febrisiantosa, A., Priyo Purwanto, B., Isnafia Arief, I., \& Widyastuti, Y. (2013). Karakteristik fisik, kimia, mikrobiologi whey kefir dan aktivitasnya terhadap penghambatan angiotensin converting enzyme (ACE). Jurnal Teknologi Dan Industri Pangan, 24(2), 147-153. https://doi.org/10.6066/jtip.2013.24.2.147
Ginting, N., \& Pasaribu, E. (2005). Pengaruh temperatur dalam pembuatan yogurt dari berbagai jenis susu dengan menggunakan lactobacillus bulgaricus dan streptococcus thermophilus the effect of temperature in making yogurt from various kind of milk, using lactobacillus bulgaricus and streptococcus thermophilus. Jurnal Agribisnis Peternakan, 1(2), 73-77.

Gonçalvez, D., Pérez, C., Reolon, G., \& Segura, N. (2009). Effect of thickeners on the texture of stirred yogurt. Alimentos e Nutrição, 9(1), 118-124.

Madora, E. P., Takalani, T. K., \& Mashau, M. E. (2016). Physicochemical, microbiological and sensory properties of low fat yogurt fortified with carrot powder. International Journal of Agricultural and Biological Engineering, 9(1), 118124. https://doi.org/10.25165/JJABE.V9I1.1874

Setianto, Y., Pranomo, Y., \& Mulyani, S. (2014). Nilai pH, viskositas, dan tekstur yogurt drink dengan penambahan ekstrak salak pondoh (Salacca zalacca). Jurnal Aplikasi Teknologi Pangan, 3(3), 110-113.

Shaker, R., Jumah, R., \& Abu-Jdayil, B. (2000). Rheological properties of plain yogurt during coagulation process: impact of fat content and preheat treatment of milk. Journal of Food Engineering, 44(3), 175-180. https://doi.org/10.1016/S0260-8774(00)00022-4

Sirotek, K., Slováková, L., Kopecný, J., \& Marounek, M. (2004). Fermentation of pectin and glucose, and activity of pectin-degrading enzymes in the rabbit caecal bacterium Bacteroides caccae. - PubMed - NCBI. Letters in Applied Microbiology, 38(4), 327-332. 
Utomo, M., Purwadi, \& Thohari, I. (2013). Pengaruh Tepung Porang (Amorohallus oncophyllus) Terhadap Kualitas Yogurt Drink Selama
Penyimpanan Pada Refrigerator dari TPC, Viskositas, Sinerisis dan $p H$. Universitas Brawijaya. Malang. 